\title{
Motor development in non-microcephalic infants born to mothers with Zika Virus infection during pregnancy
}

\author{
Desenvolvimento motor em crianças não microcefálicas nascidas de mães com infecção por \\ VIRUS ZIKA na gravidez
Desarrollo motor de niños nacidos sin microcefalia de madres infectadas por el virus del Zika durante el embarazo

Laís Rodrigues Gerzson', Carla Skilhan de Almeida², Juliana Herrero da Silva³, Lavinia Schüler-Faccini 1,3,4

\begin{abstract}
I This cross-sectional study sought to evaluate motor development in infants exposed to ZIKV born with normal head circumference (HC). Thirty one children, distributed into two groups, participated in the study: 15 whose mothers were infected by ZIKV during pregnancy, born with $\mathrm{HC}$ from -1.9 to +2 Z-scores, adjusted for sex and gestational age (exposed group); and 16 randomly selected infants without known prenatal exposure to ZIKV, paired by sex and age (control group). Alberta Infant Motor Scale (AIMS) was used to evaluate gross motor development. We found no significant difference between the exposed and control groups. However, considering that AIMS is a screening test that assesses only the gross motor development and the small size of our sample, infants exposed to ZIKV during pregnancy should be continuously evaluated for different aspects of their development.
\end{abstract}

Keywords | Zika Virus; Child Development; Physiotherapy; Brazil.

RESUMO I O objetivo do estudo foi avaliar o desenvolvimento motor de crianças expostas ao ZIKV, nascidas com perímetro cefálico normal (PC). Estudo transversal. Trinta e uma crianças participaram do estudo, distribuídas em dois grupos: 15 crianças cujas mães foram infectadas pelo ZIKV durante a gravidez, nascidas com PC medido entre $-1,9$ e +2 escores Z ajustados para sexo e idade gestacional (grupo exposto); e 16 controles aleatoriamente selecionados pareados por sexo e idade, sem exposição pré-natal conhecida ao ZIKV (grupo não exposto). Alberta Infant Motor Scale (AIMS) foi usado para avaliar o desenvolvimento motor grosso. Não houve diferenças significativas entre os grupos expostos e não expostos. Embora reconfortante, devemos destacar que o AIMS é um teste de triagem e apenas avalia o desenvolvimento motor grosso, e nossa amostra foi pequena. Portanto, crianças expostas ao ZIKV na gravidez devem ser continuamente avaliadas quanto a diferentes aspectos de seu desenvolvimento.

Descritores | Zika virus; Desenvolvimento Infantil; Fisioterapia; Brasil.

RESUMEN | El presente estudio objetivó evaluar el desarrollo motor de niños expuestos al virus del Zika nacidos con la circunferencia de la cabeza (CC) normal. Estudio transversal. Participaron 31 niños en el estudio y se distribuyeron en dos grupos: 15 niños cuyas madres habían sido infectadas por el virus del Zika durante el embarazo nacieron con CC entre $-1,9$ y +2 puntajes $Z$ ajustados por sexo y edad gestacional (grupo expuesto); y 16 controles seleccionados al azar pareados por sexo y edad, sin exposición prenatal conocida

Universidade Federal do Rio Grande do Sul (UFRGS) - Porto Alegre (RS), Brazil. E-mail: gerzson.lais@yahoo.com.br. Orcid: 0000-0002-0911-9820

Universidade Federal do Rio Grande do Sul (UFRGS) - Porto Alegre (RS), Brazil. E-mail: carlaskilhan@gmail.com. Orcid: 0000-0003-1271-2876

${ }^{3}$ Universidade Federal do Rio Grande do Sul (UFRGS) - Porto Alegre (RS), Brazil. E-mail: epidemio@tangaradaserra.mt.gov.br. Orcid: 0000-0002-5481-4603

${ }^{4}$ Hospital de Clínicas de Porto Alegre (HCPA) - Porto Alegre (RS), Brazil. E-mail: lavinia.faccini@ufrgs.br. Orcid: 0000-0002-2428-0460 
al virus del Zika (grupo no expuesto). La Alberta Infant Motor Scale (AIMS) se utilizó para evaluar el desarrollo motor grueso. No hubo diferencias significativas entre el grupo expuesto y el grupo no expuesto. A pesar de alentador, debemos destacar que la AIMS es una prueba de detección, que solo evalúa el desarrollo motor grueso, y que nuestra muestra fue pequeña. Por lo tanto, los niños expuestos al virus del Zika durante el embarazo se deben evaluar continuamente para que se identifiquen los diferentes aspectos de su desarrollo.

Palabras clave | Virus Zika; Desarrollo Infantil; Fisioterapia; Brasil.

\section{INTRODUCTION}

The sudden outbreak of infants born with microcephaly in 2015 enabled the identification of a new human teratogen: the Zika Virus (ZIKV) ${ }^{1-3}$. Babies born with this condition presented a specific pattern of "Fetal Brain Disruption Sequence," 4 characterized by small head circumference, pronounced craniofacial disproportion, overlapping cranial sutures, occipital prominence and redundant neck and head skin, joint contractures, and severe neurological disorder. Brain imaging (CT scan or MRI) detected multiple calcifications, abnormal gyral patterns, increased cerebrospinal fluid, and cortical destruction ${ }^{5,6}$. The neurological phenotype associated with ZIKV is quite impressive and distinctive from other congenital infections. It severely affects motor functions (tone, posture, and motility), and often presents generalized hypertonia, leading to extensor axial posturing and abnormal wrist position - clenched fists and difficulty in stretching the fingers. Infants also exhibit abnormal neurobehavior by inconsolable, poorly modulated, and constant crying, and by poor contact with the examiner. However, authorities were concerned that some infants born without microcephaly could present a postnatal phenotype, including postnatal microcephaly, hydrocephaly, brain calcifications, ophthalmic abnormalities, seizures, and neurological dysfunctions ${ }^{7-9}$.

It is estimated that a congenitally infected baby has about $5 \%$ chance of presenting typical congenital Zika syndrome (CZS) birth defects, and the risk is higher when infection occurs during the first half of pregnancy ${ }^{10}$. However, considering that many cases of ZIKV infections are asymptomatic, it is still difficult to assess. In particular, infants prenatally exposed to ZIKV with no microcephaly or other congenital anomaly at birth raise authorities' concern. When infection occurs during pregnancy, the virus may change the neural networks developmental phase when synaptic networks start to form and neuronal circuits increase - in which several external influences may affect fetus development ${ }^{11}$.

The outbreak of ZIKV hit the Brazilian Midwest region by the end of 2015. News about microcephaly were already public at the time, and thus many women became extremely anxious. Not even mothers of infants born with normal head circumference were reassured, as late adverse outcomes also posed concerns. Some studies show that $13.3 \%$ and $15.8 \%$ of infants born to mothers with ZIKV infection without microcephaly at birth presented delayed development of motor skills ${ }^{12,13}$. Studies in rodents found that pups born without microcephaly presented growth restriction and developmental delay ${ }^{14}$.

This work aims to evaluate gross motor development in infants exposed to ZIKV without microcephaly, at 12 and 18 months of life, compared to nonexposed infants. Future orientation and intervention strategies should be initiated in the period from conception until three first years of life, providing room for experiences and potentiating infants' gross development ${ }^{15}$.

\section{METHODOLOGY}

This was a cross-sectional observational study conducted in Tangará da Serra, Mato Grosso, Brazil (101,000 inhabitants). In 2015 and 2016, Tangará da Serra reported an outbreak of ZIKV infection with 1,717 symptomatic people, 103 of which were pregnant women. These women underwent follow-up, and 35 were confirmed positive by the reverse transcriptase polymerase chain reaction (RT-PCR) blood test.

Inclusion criteria: Cases - all live births in Tangará da Serra from January $1^{\text {st }}$ to December $31^{\text {st }} 2016$, with normal head circumference $(-1.9$ and $+2 \mathrm{Z}$-scores, adjusted by sex a gestational age according Intergrowth $21^{\text {st }}$ charts), without congenital anomalies, and born to mothers with ZIKV infection confirmed by RTPCR during pregnancy. All live births were routinely 
monitored at the maternity ward and had their head circumference measured at birth and $24 \mathrm{hs}$ later, before hospital discharge. Newborns' were also tested for STORCH, Dengue, and Chikungunya. At one year old, the Municipal Health Secretariat invited mothers to bring their children for new clinical evaluations, including dysmorphology and neurological examination, as well as the Alberta Infant Motor Scale from this study.

Exclusion criteria: infants' that tested positive for STORCH,DENV, or CHIKV, and presented microcephaly or macrocephaly at birth or any known genetic or environmental condition leading to congenital anomalies.

From this group, 15 children were included in the study; 11 could not be located (change of address); and four families disagreed to participate.

Control group: to compare with the exposed group, we randomly selected 16 babies from the same town, paired by age and sex, born to mothers without known ZIKV or other congenital infection (no symptoms, tested negative for STORCH), and with normal head circumference.

Two physiotherapists, previously trained together for two weeks to standardize the tests, evaluated the children at the same time. Evaluations were adapted to the children's routine and performed in a Family Health Unit. A structured questionnaire was applied - with information on parents' education level, profession, type of household, and number of people in the household to classify the family's socioeconomic profile and ensure sample homogenization. Clinical data was obtained from medical records.

To assess children's gross motor development, evaluators blinded to the groups (exposed or control) applied the Alberta Infant Motor Scale (AIMS) ${ }^{15}$, a userfriendly observational scale, translated and validated to the Brazilian population. The scale refers to children's motor performance and addresses 58 aspects consisting on gross motor development, neural maturation, sequence of motor skills, progress in motor function, and integration of the anti-gravitational muscle control in four positions: prone, supine, sitting, and standing. For each posture, the baby assumes a position to which a score is assigned, generating a final score.

We obtained raw scores by centile ranks, concerning infant's age and total score (abnormal if lower than $5^{\text {th }}$; suspected if between $5^{\text {th }}$ and $25^{\text {th }}$; typical if above $\left.25^{\text {th }}\right)^{16}$. The test took on average 20 minutes per child and was recorded for further analysis of children's motor performance in the four positions. For analyzing the records, the two evaluators focused on children's free movements, such as body surface area sustaining weight, position, and anti-gravitational movements.

Collected data were stored at the Statistical Package for the Social Sciences (SPSS), version 22.0. We used the student's t-test to compare means between groups. In case of asymmetry, Mann-Whitney $U$ test was used. To compare proportions, we used Pearson's chi-square test or Fisher's exact test. For all tests, we considered significance level of $5 \%$.

\section{RESULTS}

Cases and controls were highly homogeneous regarding their parent's characteristics (Table 1), differing only for father's mean education level (lower in ZIKV exposed group, $\mathrm{p}=0.033)$.

Table 1. Parent's demographic characteristics in exposed and control groups

\begin{tabular}{|c|c|c|c|}
\hline \multirow[t]{2}{*}{ Variables } & $\begin{array}{c}\text { Exposed } \\
(n=15)\end{array}$ & $\begin{array}{c}\text { Controls } \\
(n=16)\end{array}$ & \multirow[t]{2}{*}{$\mathbf{p}$} \\
\hline & n (\%) & $n(\%)$ & \\
\hline Mother's skin color & & & 0.810 \\
\hline White & $4(26.7)$ & $6(37.5)$ & \\
\hline Mixed-race & $11(73.3)$ & $9(62.5)$ & \\
\hline Mother's age (years) & & & 0.394 \\
\hline $19-35$ & $11(73.3)$ & $14(87.5)$ & \\
\hline$>35$ & $4(26.7)$ & $2(12.5)$ & \\
\hline Father's age (years) & & & 0.054 \\
\hline $19-35$ & $13(86,7)$ & $8(50)$ & \\
\hline$>35$ & $2(13.3)$ & $8(50)$ & \\
\hline $\begin{array}{l}\text { Mother's education level } \\
\text { (years) mean } \pm S D\end{array}$ & $12.7 \pm 3.9$ & $13.0 \pm 2.9$ & 0.832 \\
\hline $\begin{array}{l}\text { Father's education level } \\
\text { (years) mean } \pm S D\end{array}$ & $8.9 \pm 4,6$ & $12.2 \pm 3.7$ & 0.033 \\
\hline $\begin{array}{l}\text { Median household } \\
\text { income (P25-P75) }\end{array}$ & $\begin{array}{r}2,000 \\
(1200-5000)\end{array}$ & $\begin{array}{r}4,000 \\
(2.000-7.125)\end{array}$ & 0.101 \\
\hline
\end{tabular}

SD: standard deviation; P: percentile.

Table 2 shows infants' characteristics for both groups. We found similarities in their demographic characteristics, prenatal exposures, and perinatal outcomes, differing only for mother's alcohol intake during pregnancy (higher in the control group, $\mathrm{p}=0.037$ ). In the exposed group, maternal ZIKV infection occurred mainly during the second trimester of pregnancy $(n=9)$, followed by first trimester $(n=5)$, and a single case occurred during the third trimester. 
Table 2. Children's characteristics in exposed and control groups

\begin{tabular}{|c|c|c|c|}
\hline \multirow{2}{*}{ Variables } & $\begin{array}{c}\text { Exposed } \\
(n=15)\end{array}$ & $\begin{array}{c}\text { Controls } \\
(n=16)\end{array}$ & \multirow[t]{2}{*}{$\mathbf{p}$} \\
\hline & n (\%) & n (\%) & \\
\hline $\begin{array}{l}\text { Sex: Male } \\
\text { Gestational age }<37 \text { weeks }\end{array}$ & $\begin{array}{r}9(60) \\
4(26.7)\end{array}$ & $\begin{array}{l}9(56.3) \\
2(12.5)\end{array}$ & $\begin{array}{l}1.000 \\
0.394\end{array}$ \\
\hline Gestational age (weeks) & $37.9 \pm 2.5$ & $38.4 \pm 1.6$ & 0.508 \\
\hline Number of siblings & $2.3 \pm 1$ & $1.8 \pm 0.7$ & 0.090 \\
\hline $\begin{array}{l}\text { Number of people living in } \\
\text { the same household }\end{array}$ & $4.7 \pm 1.3$ & $4.2 \pm 1.4$ & 0.344 \\
\hline Household & & & 0.394 \\
\hline Owned & $11(73.3)$ & $14(87.5)$ & \\
\hline Rented & $4(26.7)$ & $2(12.5)$ & \\
\hline Bedroom & & & 0.848 \\
\hline Crib & $7(46.7)$ & $9(56.3)$ & \\
\hline Bed alone & $3(20)$ & $3(18.8)$ & \\
\hline Bed-sharing & $5(33.3)$ & $4(25)$ & \\
\hline Daily activities & & & 0.484 \\
\hline Walking & $1(6.7)$ & $0(0)$ & \\
\hline Playing & $14(93.3)$ & $16(100)$ & \\
\hline Prenatal visits - mean $\pm S D$ & $8.9 \pm 2.4$ & $9.5 \pm 3.8$ & 0.585 \\
\hline Birth Weight <2,500g & $1(6.7)$ & $0(0)$ & 0.086 \\
\hline Weight z-score - mean \pm SD & $0.22 \pm 1.29$ & $0.16 \pm 0.67$ & 0.889 \\
\hline HC z-score - mean $\pm S D$ & $1.37 \pm 1.32$ & $1.38 \pm 0.71$ & 0.974 \\
\hline Length z-score - mean $\pm S D$ & $-0.05 \pm 1.33$ & $0.08 \pm 0.98$ & 0.765 \\
\hline Apgar 5 - median (P25-P75) & $9(9-9)$ & $9(9-10)$ & 0.272 \\
\hline Delivery: cesarean section & $13(86.7)$ & $15(93.8)$ & 0.600 \\
\hline Trimester of ZIKV infection & & & - \\
\hline $1^{\circ}$ & $5(33.3)$ & - & \\
\hline $2^{\circ}$ & $9(60)$ & - & \\
\hline $3^{\circ}$ & $1(6.7)$ & - & \\
\hline Mother's alcohol intake & $1(6.7)$ & $7(43.8)$ & 0.037 \\
\hline Mother's smoking habits & $0(0)$ & $2(12.5)$ & 0.484 \\
\hline
\end{tabular}

SD: standard deviation; HC: head circumference.

At the time of the test, children's age ranged between 12 and 18 months $(16.5 \pm 1.69)$. Table 3 shows children's gross motor development considering total score, motor percentile score, and positions score for both groups. Both groups presented similar results for AIMS evaluation - most children were within the typical development expected for their chronological age. One infant in each group (6.7\% in exposed; $6.3 \%$ in controls) was classified with suspected developmental delay. Infants in both groups achieved almost the same scores for the prone, supine, seating and standing positions, as well as the total score $(\mathrm{p}=0.48)$. Motor centiles were also similar in exposed and controls $(65.5 \pm 16.8$ vs $64.4 \pm 18.4 ; \mathrm{p}=0,86$ ).
Table 3. AIMS total score, motor centile score, and positions scores for exposed and control groups

\begin{tabular}{lrrr} 
& Exposed $(\mathrm{n}=15)$ & Controls $(\mathrm{n}=16)$ & \multirow{2}{*}{$\mathbf{p}^{*}$} \\
\cline { 2 - 3 } AlMS Score & Mean \pm SD & Mean \pm SD & \\
Prone & $20.9 \pm 0.3$ & $20.8 \pm 1$ & 0.497 \\
Supine & $9 \pm 0$ & $9 \pm 0$ & 1.000 \\
Seating & $11.9 \pm 0.3$ & $11.9 \pm 0.5$ & 0.689 \\
Standing & $15.7 \pm 1$ & $15.4 \pm 1.5$ & 0.539 \\
Total & $57.6 \pm 1.1$ & $57.1 \pm 2.7$ & 0.483 \\
Motor (centile) & $65.5 \pm 16.8$ & $64.4 \pm 18.4$ & 0.864 \\
Classification & $n(\%)$ & $n(\%)$ & 1.000 \\
Typical & $14(93.3)$ & $15(93.8)$ & \\
Suspect & $1(6.7)$ & $1(6.3)$ &
\end{tabular}

SD: standard deviation; AIMS: Alberta Infant Motor Scale.

\section{DISCUSSION}

Many studies describe developmental outcomes among infants born with microcephaly whose mothers were infected by ZIKV during pregnancy ${ }^{12,16-18}$. Yet, little is known about these children's long-term development, raising concern particularly for their mothers ${ }^{19-21}$. Some studies show developmental delay in approximately $15 \%$ of infants born to ZIKV infected mothers without microcephaly at birth. Our study found one infant with suspected delay in 15 exposed cases (6.7\%), but the same occurred in the control group (6.3\%). Although limited in size, our investigation was a population-based study, geographically limited, uniform in socioeconomic status, and with a control group of children born in the same city and paired by age. We found no risk factor other than mother's alcohol intake during pregnancy, which was higher in the control group.

We chose AIMS for comprising a simple and reliable test to evaluate gross motor development in young children that was validated in Brazil. Our study group was in their second year of life (12-18 months), a prone age for motor development evaluation, as infants should be already walking and presenting specific motor skills. Differences between our and previous studies might be explained by infant's age during evaluation. Cardoso Jr. et al..$^{13}$ evaluated the development of 19 children using AIMS, and classified three of them - whose mothers were infected during the first $(n=1)$ and second $(n=2)$ trimester of pregnancy - with developmental delay. However, analyzed infants were only 4 months old or younger, and thus the test results cannot be comparable with ours. 
The timing of gestational exposure to ZIKV is also an important factor in possible outcomes: infections that occur early in pregnancy are associated to the more severe phenotype, particularly microcephaly ${ }^{22}$. Even so, ZIKV can inflict harm during all gestational trimesters, especially the fourteenth and seventeenth weeks ${ }^{23}$. First trimester exposures may produce more severe morphologic abnormalities. Later exposures, during the second and third gestational trimesters, often result in more qualitative changes in cognition and behavior, due to changes in neuronal networks. During the period of fetal development, cortical maturation occurs, neural and glial migration continues, and neural networks are organized, influencing motor, sensory, and cognitive functional abilities ${ }^{24}$.

Faiçal et al. ${ }^{14}$ evaluated 29 normocephalic children with in utero exposure to ZIKV using the Bayley Scales of Infant and Toddler Development III, and found ten (35\%) infants with neurodevelopment delay, nine (31\%) with language delay, four (14\%) with cognitive delay, and 1 (3\%) with motor delay. Although evaluated with a different instrument, normocephalic children born to mother infected with ZIKV during pregnancy seem to be less affected in motor development than in language and cognition. Our study did not evaluate cognitive abilities, language, and behavior at this moment; further studies should be performed, applying tests designed for this endpoints.

Our study also presents the limitation of having only mother's laboratory confirmation tests and no Plaque Reduction Neutralization Test (PRNT) from exposed infants, thus without proven fetal exposure.

Although reassuring, considering that AIMS is a screening test that assesses only motor development and that our sample was limited in size, children exposed to ZIKV during pregnancy should be continuously evaluated for different aspects of their development.

\section{ACKNOWLEDGEMENTS}

Laís Gerzson holds a PHD scholarship from CAPES (Brazilian Ministry of Education).

\section{REFERENCES}

1. Rasmussen SA, Jamieson DJ, Honein MA, Petersen LR. Zika Virus and birth defects-reviewing the evidence for causality. N Engl J Med. 2016;374(20):1981-7. doi: 10.1056/NEJMsr1604338
2. Schuler-Faccini L, Sanseverino MTV, Vianna FSL, Silva AA, Larrandaburu M, Marcolongo-Pereira C, et al. Zika Virus: a new human teratogen? Implications for women reproductive age. Clin Pharmacol Ther. 2016;100(1):28-30. doi: 10.1002/cpt.386

3. Schuler-Faccini L, Ribeiro EM, Feitosa IML, Horovitz DDG, Cavalcanti DP, Pessoa A, et al. Possible Association Between Zika Virus Infection and Microcephaly - Brazil, 2015. Morb Mortal Wkly Rep. 2016;65(3):59-62. doi: 10.15585/mmwr.mm6503e2

4. Russell LJ, Weaver DD, Bull MJ, Weinbaum M, Opitz JM. In utero brain destruction resulting in collapse of the fetal skull, microcephaly, scalp rugae, and neurologic impairment: the fetal brain disruption sequence. Am J Med Genet. 1984;17(2): 509-21. doi: 10.1002/ajmg.1320170213

5. Moore CA, Staples JE, Dobyns WB, Pessoa A, Ventura CV, Fonseca EB, et al. Characterizing the pattern of anomalies in congenital Zika syndrome for pediatric clinicians. JAMA Pediatr. 2017;171(3):288-95. doi: 10.1001/jamapediatrics.2016.3982

6. Del Campo M, Feitosa IM, Ribeiro EM, Horovitz DD, Pessoa AL, França GV, et al. The phenotypic spectrum of congenital Zika syndrome. Am J Med Genet A. 2017;173(4):841-57. doi: 10.1002/ ajmg.a.38170

7. Aragao M, Holanda AC, Brainer-Lima AM, Petribu NCL, Castillo $M$, Van der Linden $V$, et al. Nonmicrocephalic Infants with Congenital Zika Syndrome Suspected Only after Neuroimaging Evaluation Compared with Those with Microcephaly at Birth and Postnatally: How Large Is the Zika Virus "Iceberg"? AJNR Am J Neuroradiol. 2017;38(7):1427-34. doi: 10.3174/ajnr.A5216

8. Van der Linden V, Pessoa A, Dobyns W, Barkovich AJ, Van der Linden $\mathrm{H}$ Jr, Rolim Filho EL, et al. Description of 13 Infants Born During October 2015-January 2016 With Congenital Zika Virus Infection Without Microcephaly at Birth - Brazil. MMWR Morb Mortal Wkly Rep. 2016;65(47):1343-8. doi: 10.15585/mmwr. mm6547e2

9. Zin AA, Tsui I, Rossetto J, Vasconcelos Z, Adachi K, Valderramos $S$, et al. Screening criteria for ophthalmic manifestations of congenital Zika virus infection. JAMA Pediatr. 2017;171(9):847-54. doi: 10.1001/jamapediatrics.2017.1474

10. Honein MA, Dawson AL, Petersen EE, Jones AM, Lee EH, Yazdy MM, et al. Birth Defects Among Fetuses and Infants of US Women With Evidence of Possible Zika Virus Infection During Pregnancy. JAMA. 2017;317(1):59-68. doi: 10.1001/jama.2016.19006

11. Babenko O, Kovalchuk I, Metz GA. Stress-induced perinatal and transgenerational epigenetic programming of brain development and mental health. Neurosci Biobehav Rev. 2015;48:70-91. doi: 10.1016/j.neubiorev.2014.11.013

12. Cabral J, Faiçal A, Almeida B, Oliveira JV, Embiruçu E, Ferreira, N, et al. Neurodevelopmental delays arising from in utero exposure to Zika virus in Salvador, Brazil. Int J Infect Dis. 2018;73:48-9. doi: 10.1016/j.ijid.2018.04.3533

13. Cardoso TF Jr, Santos RSD, Corrêa RM, Campos JV, Silva RB, Tobias CC, et al. Congenital Zika infection: neurology can occur without microcephaly. Arch Dis Child. 2019;104(2):199-200. doi: 10.1136/archdischild-2018-314782

14. Faiçal AV, Oliveira JC, Oliveira JVV, Almeida BL, Agra IA, Alcantara LCJ, et al. Neurodevelopmental delay in normocephalic children with in utero exposure to Zika virus. BMJ Paediatr Open. 2019:3(1):e000486. doi: 10.1136/bmjpo-2019-000486 
15. Piper MC, Darrah J. Motor assessment of the developing infant. Philadelphia: Saunders; 1994.

16. Valentini NC, Pereira KRG, Santos Chiquetti EM, Formiga CKMR, Linhares MBM. Motor trajectories of preterm and full-term infants in the first year of life. Pediatr Int. 2019. doi: 10.1111/ped.13963

17. Botelho ACG, Neri LV, Silva MQF, Lima TT, Santos KG, Cunha RMA, et al. Presumed congenital infection by Zika virus: findings on psychomotor development-a case report. Rev Bras Saúde Matern Infant. 2016;16(1):39-44. doi: 10.1590/1806-9304201600s100004

18. Flor CJDRV, Guerreiro CF, Anjos JLM. Desenvolvimento neuropsicomotor em crianças com microcefalia associado ao Zika Vírus. Rev Pesqui Fisioter. 2017;7(3):313-8. doi: 10.17267/2238-2704rpf.v7i3.1386

19. Melo A, Gama GL, Silva RA Jr, Assunção PL, Tavares JS, Silva MB et al. Motor function in children with congenital Zika syndrome. Dev Med Child Neurol. 2019; 62(2):221-6. doi: 10.1111/dmcn.14227

20. Ferreira HNC, Schiariti V, Regalado ICR, Sousa KG, Pereira SA, Fechine CPNDS, et al. Functioning and Disability Profile of Children with Microcephaly Associated with Congenital Zika
Virus Infection. Int J Environ Res Public Health. 2018;15(6):1107. doi: 10.3390/ijerph15061107

21. Krow-Lucal ER, Andrade MR, Cananéa JNA, Moore CA, Leite $\mathrm{PL}$, Biggerstaff BJ, et al. Association and birth prevalence of microcephaly attributable to Zika virus infection among infants in Paraíba, Brazil, in 2015-16: a case-control study. Lancet Child Adolesc Health. 2018;2(3):205-13. doi: 10.1016/S2352-4642(18)30020-8

22. Castro MC, Han QC, Carvalho LR, Victora CG, França GVA. Implications of Zika virus and congenital Zika syndrome for the number of live births in Brazil. Proc Natl Acad Sci USA. 2018;115(24):6177-82. doi: 10.1073/pnas.1718476115

23. Paul AM, Acharya D, Neupane B, Thompson EA, GonzalezFernandez G, Copeland KM, et al. Congenital Zika Virus Infection in Immunocompetent Mice Causes Postnatal Growth Impediment and Neurobehavioral Deficits. Front Microbiol. 2018;9:2028. doi: 10.3389/fmicb.2018.02028

24. Brasil P, Pereira JP Jr, Moreira ME, Ribeiro Nogueira RM, Damasceno L, Wakimoto M, et al. Zika virus infection in pregnant women in Rio de Janeiro. N Engl J Med.2016;375(24):2321-34. doi: 10.1056/NEJMoa1602412 